\title{
Production and chemical composition of three sugarcane cultivars grown under Af climate conditions
}

\author{
Augusto Sousa Miranda', Felipe Nogueira Domingues², Bruno Spacek Godoy², Ricardo \\ Pedroso Oaigen ${ }^{4}$, Aníbal Coutinho do Rêgo ${ }^{5}$, Cristian Faturi ${ }^{5}$, Renato Pinto Corrêa ${ }^{2}$, Flávio da \\ Silva ${ }^{2}$
}

\footnotetext{
${ }^{1}$ Universidade Federal do Pará, Programa de Pós-graduação em Ciência Animal, Castanhal, PA, Brasil.

2 Universidade Federal do Pará, Faculdade de Medicina Veterinária, Castanhal, PA, Brasil.

${ }^{3}$ Universidade Federal do Pará, Núcleo de Ciências Agrárias e Desenvolvimento Rural, Belém, PA, Brasil.

${ }^{4}$ Universidade Federal do Pampa, Faculdade de Medicina Veterinária, Uruguaiana, RS, Brasil.

${ }^{5}$ Universidade Federal Rural da Amazônia, Instituto de Saúde e Produção Animal, Belém, PA, Brasil.
}

\begin{abstract}
The objective of this study was to evaluate the chemical composition and yield of three sugarcane cultivars grown under Af climate conditions. Three sugarcane cultivars were examined, namely, IACSP93-6006, RB83-5486, and SP79-1011, in a randomized block design with three treatments, four blocks, and two replicates per block; means were compared using Tukey's test at 5\% probability level. Significant differences were observed for dry matter, ether extract, crude protein, acid detergent fiber, lignin (LIG), cellulose, neutral detergent fiber corrected for ash and protein (NDFap), total carbohydrates, carbohydrate fractions B2 and C, and dry matter yield. The fiber components (NDFap, LIG, and fraction C) displayed low values. The cultivars produced high dry matter yields, especially IACSP93-6006 and SP79-1011. There were no differences among sucrose (Pol) values and the NDF/Pol ratios. The low Pol values indicate that sugarcane grown under Af climate conditions does not produce high levels of sucrose. The three sugarcane cultivars grown under the Af climate conditions produce high yields of DM/ha but low concentrations of the fiber components, as well as low Pol concentrations.
\end{abstract}

Key Words: neutral detergent fiber, ruminant nutrition, Saccharum officinarum

\section{Introduction}

Climatic factors influence sugarcane crops, especially rainfall, air temperature, and solar radiation. Each climate type has striking characteristics regarding factors that can influence the yield and technological quality of sugarcane, and the final result represents the interaction of the various conditions to which the crop was subjected (Gilbert et al., 2006).

The Af climate type, as defined by the Köppen-Geiger climate classification (better known as the Köppen climate classification), is characterized as a humid tropical climate with rainfall throughout the year, a minimum annual temperature above $18{ }^{\circ} \mathrm{C}$, and no well-defined dry season (Peel et al., 2007). This type of climate occurs in the following Brazilian states: $70.5 \%$ of Acre, $0.4 \%$ of Alagoas, $82.3 \%$ of Amazonas, $9.0 \%$ of Bahia, $2.9 \%$ of Espírito Santo, $6.6 \%$ of Mato Grosso do Sul, $28.4 \%$ of Pará, $2.1 \%$ of Rio de

Received September 30, 2014 and accepted August 9, 2015

Corresponding author: felipend@gmail.com

http://dx.doi.org/10.1590/S1806-92902015001100002

Copyright (C) 2015 Sociedade Brasileira de Zootecnia. This is an Open Access article distributed under the terms of the Creative Commons Attribution License (http://creativecommons.org/licenses/by/4.0/), which permits unrestricted use, distribution, and reproduction in any medium, provided the original work is properly cited.
Janeiro, $38.8 \%$ of Roraima, and $1.9 \%$ of São Paulo, across a total of $22.6 \%$ of the Brazilian territory (Alvarez et al., 2014).

Several studies on sugarcane have been conducted under various climate types: Aw (Cruz et al., 2010; Capone et al., 2011), Am (Townsend et al., 2006), Cwa (Macêdo et al., 2012), Cfa (Muraro et al., 2009), and BSh (Almeida et al., 2008).

Evaluations of sugarcane cultivars that can adapt to local soil and climate conditions, as well as determinations of their nutritional characteristics, are important and relevant in order to provide support to farmers, creating and evaluating alternatives for improving the animal feeding system.

The present study evaluated the yield and the chemical composition of three sugarcane cultivars grown under Af climate conditions.

\section{Material and Methods}

The experiment was conducted in the city of Castanhal, state of Pará ( $65 \mathrm{~m}$ altitude, $01^{\circ} 18^{\prime} \mathrm{S}$ latitude and $47^{\circ} 55^{\prime} \mathrm{W}$ longitude). The regional climate type is Af according to the Köppen classification system (Peel et al., 2007). The values of precipitation and temperature during the experimental period from June 2010 to October 2013 were similar to the average of the previous thirty years (Figure 1 and Table 1). 
The three sugarcane cultivars, namely, IACSP93-6006, RB83-5486, and SP79-1011, used in the present study, were acquired from the Federal Institute of Education, Science and Technology of Pará, Castanhal Campus. These cultivars were selected because they have been used as ruminant feed by ranchers in the region.

The experimental plots consisted of four rows of four meters in length with 1-m spacing between rows. For the evaluation of the crop, the marginal rows and a 1-m length at the ends of the central rows were disregarded, and only the two linear meters of the two central rows from each plot were considered as usable area for evaluation.

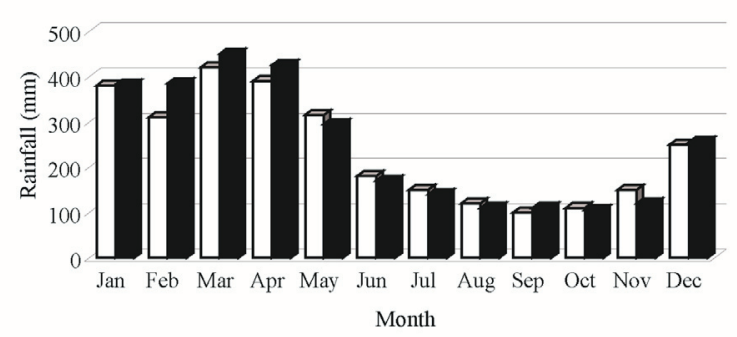

$\square$ Mean rainfall in the 3 years of the experiment $\square$ Mean rainfall in the previous 30 years

Source: data obtained from the automatic weather station of Instituto Nacional de Meteorologia, Belém-PA, Brazil (INMET, 2014).

Figure 1 - Mean rainfall for the previous thirty years and for the experimental period (mean of 3 years).
Soil samples were collected for chemical analyses. The results of the chemical analyses of the soil were determined before the implementation of the experiment and after each harvest (Table 2).

To implement the experiment, 2 t.ha ${ }^{-1}$ of dolomitic limestone were applied 60 days before planting. During tillage, two harrowings were conducted, the first with a disc harrow and the second with a leveling harrow. Subsequently, the furrows were opened for the planting of the stalks, with 1-m spacing between furrows and $25-\mathrm{cm}$ depth. Planting was performed manually in June 2010, with the stalks distributed in the furrows such that the basal portion of a seedling was in contact with the apical portion of the subsequent one, at a density of 15-18 buds per linear meter, and subsequently sectioned into portions of 3-4 buds.

The amount of fertilizer used during planting, first ratoon, and second ratoon were calculated from the results of the soil analyses. To achieve a yield of 100 t.ha $^{-1}$ of fresh matter (FM), 50, 120, and $120 \mathrm{~kg} \cdot \mathrm{ha}^{-1} \mathrm{~N} ; 140,70$, and $40 \mathrm{~kg} \cdot \mathrm{ha}^{-1} \mathrm{P}_{2} \mathrm{O}_{5}$; and 140, 150, and $160 \mathrm{~kg} \cdot \mathrm{ha}^{-1} \mathrm{~K}_{2} \mathrm{O}$ were applied in the first, second, and third crop years, respectively. Phosphorus was applied inside the furrow at the time of planting, and all of the other fertilizer applications were performed by broadcasting. During the second ratoon crop, $1 \mathrm{t} /$ ha dolomitic limestone (PRNT 90\%) was applied.

Table 1 - Mean maximum and minimum temperatures and mean annual temperature for the previous 30 years and for the experimental period (mean of 3 years)

\begin{tabular}{|c|c|c|c|c|c|c|}
\hline \multirow[b]{2}{*}{ Month } & \multicolumn{3}{|c|}{ Temperature $\left({ }^{\circ} \mathrm{C}\right) 30$-year mean } & \multicolumn{3}{|c|}{ Temperature $\left({ }^{\circ} \mathrm{C}\right)$ experiment mean } \\
\hline & Mean & Maximum & Minimum & Mean & Maximum & Minimum \\
\hline January & 26.0 & 31.0 & 22.7 & 26.2 & 34.1 & 21.8 \\
\hline February & 25.8 & 30.7 & 22.8 & 26.1 & 33.9 & 22.2 \\
\hline April & 26.2 & 31.1 & 23.1 & 26.4 & 33.7 & 22.2 \\
\hline May & 26.5 & 31.8 & 23.1 & 26.7 & 33.8 & 22.7 \\
\hline June & 26.5 & 31.9 & 22.8 & 26.7 & 33.7 & 22.1 \\
\hline September & 26.8 & 32.7 & 22.5 & 27.3 & 34.8 & 22.2 \\
\hline October & 27.0 & 32.6 & 22.4 & 27.3 & 34.6 & 22.0 \\
\hline November & 27.1 & 32.6 & 22.7 & 27.4 & 34.5 & 22.1 \\
\hline December & 26.7 & 32.1 & 22.8 & 27.0 & 34.1 & 21.8 \\
\hline
\end{tabular}

Source: data obtained from the automatic weather station of Instituto Nacional de Meteorologia, Belém-PA, Brazil (INMET, 2014).

Table 2 - Soil analysis of the experimental area during the three crop years ${ }^{1}$

\begin{tabular}{lcccccccccccc}
\hline & \multirow{2}{*}{ Year } & $\mathrm{pH}$ & $\mathrm{OM}$ & $\mathrm{P}$ & $\mathrm{H}^{+}+\mathrm{Al}^{+3}$ & $\mathrm{Al}^{+3}$ & $\mathrm{Ca}^{+2}$ & $\mathrm{Mg}^{+2}$ & $\mathrm{~K}^{+}$ & $\mathrm{SB}$ & $\mathrm{CEC}$ & $\mathrm{V}$ \\
\cline { 3 - 10 } & & $\mathrm{g} / \mathrm{kg}$ & $\mathrm{mg} / \mathrm{dm}^{3}$ & ---1 & 0.0 & 1.2 & 0.4 & 0.6 & 2.2 & 6.3 \\
\hline I & 5.1 & 35.0 & 18.0 & 4.1 & 0.1 & 3.0 & 0.8 & 2.9 & 6.7 & 10.2 & 65.8 \\
II & 6.0 & 19.5 & 25.0 & 3.5 & 0.1 & 2.2 & 0.5 & 3.1 & 5.8 & 9.4 & 61.1 \\
III & 6.7 & 24.0 & 26.0 & 3.6 & 0.1 &
\end{tabular}

pH - potential of hydrogen; $\mathrm{OM}$ - organic matter; $\mathrm{P}$ - phosphorus; $\mathrm{H}^{+}+\mathrm{Al}^{+3}$ - potential acidity; $\mathrm{Al}^{+3}$ - aluminum; $\mathrm{Ca}^{+2}-\mathrm{calcium} ; \mathrm{Mg}^{+2}-\mathrm{magnesium} ; \mathrm{K}+$ - potassium; $\mathrm{SB}-$ sum of bases; CEC - cation exchange capacity; V\% - percentage of base saturation.

${ }^{1}$ Ultisol soil with a sandy texture (Valente et al., 2001). 
Weed control was accomplished through herbicide applications. Forpre-emergence, the3-(3,4-dichlorophenyl)1,1-dimethylurea $(500 \mathrm{~g} / \mathrm{L})$ herbicide was applied at a dose of $3 \mathrm{~L} / \mathrm{ha}$, after planting and at each harvest. Sixty days after planting, the 3-chloro-5-(4,6-dimethoxypyrimidin2-ylcarbamoylsulfamoyl)-1-methylpyrazole-4-carboxylic acid $(750 \mathrm{~g} / \mathrm{kg})$ herbicide was applied for the control of purple nutsedge (Cyperus rotundus), at a dose of $17.1 \mathrm{~g} / \mathrm{ha}$. After 90 days, N-(phosphonomethyl) glycine $(480 \mathrm{~g} / \mathrm{L})$ was applied at a dose of $3.2 \mathrm{~L} / \mathrm{ha}$, protecting the plot rows with tarpaulin to avoid application of the herbicide on the sugarcane plants. The applications were performed manually with a backpack sprayer, with the operator properly dressed with personal protective equipment.

The sugarcane was harvested manually for all crop cycles, when the plant was approximately thirteen months old. To determine the fresh matter yield (FMY), all the sugarcane plants in the usable area were collected and weighed.

Seven stalks were collected from the usable area of each plot, identified, and sent in their entirety to the laboratory for determination of the Pol content of the sugarcane juice using a polarimeter, according to the Consecana protocol (2006).

The remainder of the sugarcane plants from the usable area was crushed in a stationary forage chopper to obtain a $1-\mathrm{cm}$ particle size and homogenized; Samples of approximately $0.5 \mathrm{~kg}$ of the crushed-sugarcane fresh matter were packed in plastic bags, labeled, and stored in a freezer $\left(-5^{\circ} \mathrm{C}\right)$ until the chemical analysis.
Samples were placed in a forced-air oven at $55{ }^{\circ} \mathrm{C}$ until a constant weight was achieved and then immediately ground in a Wiley mill through a $1.0-\mathrm{mm}$-diameter sieve.

The laboratory analysis consisted of the determinations of dry matter (DM), organic matter (OM), mineral matter $(\mathrm{MM})$, and crude protein (CP) by the micro Kjeldahl method, and of ether extract (EE) by the Goldfisch method (AOAC, 1990). The contents of neutral detergent fiber (NDF) and acid detergent fiber (ADF) were determined by the sequential method according to techniques described by Van Soest et al. (1991). For the determination of lignin (LIG), 72\% sulfuric acid was used (Van Soest et al., 1991). The hemicellulose (HEM) content was calculated as the difference between the NDF and the ADF, and the cellulose (CEL) content was calculated as the difference between ADF and LIG.

Carbohydrate fractionation was determined as described by Sniffen et al. (1992). Total carbohydrates were determined by the expression $\mathrm{TC}=100-(\% \mathrm{CP}+\% \mathrm{EE}+$ $\% \mathrm{MM})$. The non-fiber carbohydrates were determined by the following expression: $\mathrm{NFC}=100-(\mathrm{CP}+\mathrm{EE}+\mathrm{NDFap}$ + MM), according to Hall (2003), in which NDFap is equivalent to the cell wall corrected for ash and protein. The $\mathrm{B} 2$ fraction was determined by the following expression: $\mathrm{B} 2$ fraction $=\mathrm{NDF}-(\mathrm{NDIN} \times 0.01 \times \mathrm{CP})-\mathrm{C}$. The $\mathrm{C}$ fraction was determined by the following expression: $\mathrm{C}$ fraction $=$ $\mathrm{NDF} \times 0.01 \times \mathrm{LIG} \times 2.4$.

Estimates of the truly digestible nutrients and the total digestible nutrients (TDN) were calculated by the

Table 3 - Yield and chemical composition of the sugarcane cultivars, means from three harvests

\begin{tabular}{|c|c|c|c|c|}
\hline Item & IACSP93-6006 & RB83-5486 & SP79-1011 & SEM \\
\hline Fresh matter yield ${ }^{1}$ & $339.02 \mathrm{a}$ & $250.16 \mathrm{~b}$ & $321.52 \mathrm{a}$ & 22.47 \\
\hline Dry matter yield ${ }^{2}$ & $81.46 \mathrm{a}$ & $56.58 \mathrm{~b}$ & $77.10 \mathrm{a}$ & 5.50 \\
\hline Dry matter ${ }^{3}$ & $240.30 \mathrm{a}$ & $226.22 b$ & $239.85 \mathrm{a}$ & 0.18 \\
\hline Mineral matter ${ }^{4}$ & $15.25 \mathrm{a}$ & $15.04 \mathrm{a}$ & $14.85 \mathrm{a}$ & 0.04 \\
\hline Ether extract ${ }^{4}$ & $15.30 \mathrm{ab}$ & $16.61 \mathrm{a}$ & $14.11 \mathrm{~b}$ & 0.04 \\
\hline Crude protein ${ }^{4}$ & $17.11 \mathrm{~b}$ & $19.12 \mathrm{a}$ & $14.05 \mathrm{c}$ & 0.04 \\
\hline Neutral detergent fiber ${ }^{4}$ & 453.09 & 456.10 & 465.60 & 0.34 \\
\hline Acid detergent fiber ${ }^{4}$ & $268.55 b$ & $271.81 \mathrm{~b}$ & $285.24 \mathrm{a}$ & 0.23 \\
\hline Lignin $^{4}$ & $54.80 \mathrm{a}$ & $46.83 b$ & $52.21 \mathrm{a}$ & 0.08 \\
\hline Hemicelullose $^{4}$ & $184.54 \mathrm{a}$ & $184.29 \mathrm{a}$ & $180.35 \mathrm{a}$ & 0.18 \\
\hline Celullose $^{4}$ & $213.74 b$ & $224.97 \mathrm{a}$ & $233.03 a$ & 0.24 \\
\hline NDFap $^{4}$ & $448.90 b$ & $451.53 \mathrm{ab}$ & $462.33 a$ & 0.34 \\
\hline Non-fiber carbohydrates ${ }^{4}$ & $503.42 \mathrm{a}$ & $497.68 \mathrm{a}$ & $494.65 \mathrm{a}$ & 0.37 \\
\hline Total carbohydrates ${ }^{4}$ & $950.05 b$ & $948.73 b$ & $953.22 \mathrm{a}$ & 0.88 \\
\hline $\mathrm{B} 2^{4}$ & $322.18 b$ & $333.36 \mathrm{a}$ & $326.79 \mathrm{ab}$ & 3.95 \\
\hline $\mathrm{C}^{4}$ & $137.98 \mathrm{a}$ & $128.38 b$ & $135.07 \mathrm{a}$ & 2.51 \\
\hline $\mathrm{Pol}^{5}$ & $116.15 \mathrm{a}$ & $111.10 \mathrm{a}$ & $112.90 \mathrm{a}$ & 0.13 \\
\hline $\mathrm{NDF} / \mathrm{Pol}$ & $3.93 \mathrm{a}$ & $4.17 \mathrm{a}$ & $4.15 \mathrm{a}$ & 0.05 \\
\hline Total digestible nutrients ${ }^{4}$ & 663.11 & 670.65 & 664.80 & 0.20 \\
\hline
\end{tabular}

NDFap - neutral detergent fiber corrected for ash and protein; B2 - B2 fraction of carbohydrates; C - C fraction of carbohydrates; Pol - sucrose content of the sugarcane juice; $\mathrm{NDF} / \mathrm{Pol}$ - ratio of neutral detergent fiber to sucrose; SEM - standard error of the mean.

${ }^{1} \mathrm{t} \mathrm{ha}^{-1}$.

2 tDM ha ${ }^{-1}$.

${ }^{3} \mathrm{~g} \mathrm{~kg}^{-1}$ feed.

${ }^{4} \mathrm{~g} \mathrm{~kg}^{-1}$ dry matter.

$5 \mathrm{~g} \mathrm{~kg}^{-1}$ sugarcane juice. 
following equations from the National Research Council $(\mathrm{NRC}, 2001): \mathrm{TDN}(\%)=\mathrm{NFCtd}+\mathrm{CPtd}+($ EEtd $\times 2.25)$ + NDFtd -7 , in which NFCtd $=0.98 \times(100-[(\mathrm{NDF}$ $-\mathrm{NDICP})+\mathrm{CP}+(\mathrm{EE}-1)+\mathrm{MM}]) \times \mathrm{AF} ; \mathrm{CPtd}=\mathrm{CP} \times$ $\exp [-1.2 \times(\mathrm{ADIP} / \mathrm{CP})] ; \mathrm{EEtd}=\mathrm{EE}-1 ; \mathrm{NDFtd}=0.75 \times$ $(\mathrm{NDF}-\mathrm{LIG}) \times\left[1-(\mathrm{LIG} / \mathrm{NDF})^{0.667}\right]$. The value 7 refers to the TDN of the fecal metabolism; $\mathrm{AF}=$ adjustment factor (fodder is equal to 1); ADIP = acid detergent insoluble protein; $\mathrm{td}=$ true digestibility.

The experiment was conducted in a completely randomized design with two blocks, divided into spatial (local) and temporal (year) blocks. There were eight replicates per treatment. The means were analyzed by analyses of variance and compared by Tukey's test at 5\% probability. To determine whether there were differences in the climatic data among the experimental years, a nonparametric Kolmogorov-Smirnov test was applied at the $5 \%$ probability level.

\section{Results and Discussion}

Based on the similarity of the topography and the soil of the experimental area, which was only $600 \mathrm{~m}^{2}$, and on the fact that there were no differences in rainfall or minimum temperatures between the experimental years, the results are discussed taking into account only the treatment effect (cultivars). Thus, the experimental design blocks are considered only to decrease the variance of the treatments and thus render the test more sensitive.

The cultivars produced high FMY and high dry matter yield (DMY) (Table 3), and the yields of the IACSP93-6006 and SP79-1011 cultivars were greater than those of the RB83-5486 cultivar. This difference was attributed to the influence of climatic factors. Under the Af climate conditions, the temperature is constant throughout the year and, even in months of lower rainfall, the volume of rain is greater than $100 \mathrm{~mm}$, which provides a favorable environment for plant growth and therefore a high yield per hectare.

The DMY under the Af climate conditions were higher than those obtained for other climate types. Bonomo et al. (2009) observed DMY values of $24.59 \mathrm{tDM} \mathrm{ha}^{-1}$ for the cultivar RB83-5486 under BSh climate conditions. Townsend et al. (2006) evaluated sugarcane under Am climate conditions and reported a DMY of $52 \mathrm{t} \mathrm{ha}^{-1}$ for cultivar SP79-1011. Andrade et al. (2003) recorded DMY of 39.88 and 31.50 tha $^{-1}$ for cultivars RB83-5486 and SP79-1011, respectively, when grown under $\mathrm{Cwb}$ climate conditions.

There were significant differences in the percentage of dry matter $(\mathrm{P}<0.05)$ among the cultivars. The IACSP93-
6006 and SP79-1011 cultivars produced higher DM values than RB83-5486. However, the mean values $\left(235.45 \mathrm{~g} \mathrm{~kg}^{-1}\right.$ feed) were low compared with those reported in other studies conducted under various climatic conditions. In studies conducted under Cwa, Bsh, Cwb, and Am climates, sugarcane dry matter values ranging from 260.0 to $300.0 \mathrm{~g} \mathrm{~kg}^{-1}$ feed were observed (Mello et al., 2006; Townsend et al., 2006; Bonomo et al., 2009).

The low dry matter content for sugarcane observed in this study is related to the harvest time of the material. During the experiment, the mean rainfall in the harvest months was $123 \mathrm{~mm}$. According to Muraro et al. (2009), excess rain in the harvest months increases the water content in the plant.

There was no difference $(\mathrm{P}>0.05)$ in the $\mathrm{MM}$ content among cultivars, and the values were lower than those found in the literature for sugarcane grown under other types of climate.

Significant differences $(\mathrm{P}>0.05)$ among the levels of $\mathrm{CP}$ and $\mathrm{EE}$ were observed. Cultivar RB83-5486 contained a higher CP content compared with the other cultivars. In regard to EE, cultivar RB83-5486 contained a higher content than SP79-1011 and an equal amount to IACSP93-6006.

The CP, EE, and MM levels of the sugarcane cultivars were low, which is a feature of this fodder crop and the reason why these variables were not much influenced by the climate.

There were no differences in the contents of NDF and HEM among the cultivars. Cultivar SP79-1011 contained a higher ADF content. Cultivar RB83-5486 displayed a lower LIG content. In regard to the levels of CEL and NDFap, significant differences $(\mathrm{P}<0.05)$ were observed among cultivars, with higher CEL concentrations in the RB83-5486 and SP79-1011 cultivars. Cultivar IACSP936006 contained the lowest NDFap content.

The NFC represents half of the carbohydrates in the cultivars, which is a positive factor because the non-fiber carbohydrates ( $\mathrm{A}+\mathrm{B} 1$ fractions) are easily degraded in the rumen (Van Soest, 1994) and provide greater energy to the animals compared with the fiber carbohydrates. Cruz et al. (2010) evaluated carbohydrate fractionation among sugarcane cultivars and reported that the NFC content positively influences the levels of total digestible nutrients. Mello et al. (2006) evaluated sugarcane cultivated under Cwa climate conditions and reported NFC values of 501.4 and $497.0 \mathrm{~g} \mathrm{~kg}^{-1} \mathrm{DM}$ for the RB83-5486 and SP79-1011 cultivars, respectively, which are values similar to those found in the present study. 
Significant differences $(\mathrm{P}<0.05)$ were observed among cultivars in the levels of TC, the B2 fraction, and the $\mathrm{C}$ fraction (Table 3). Cultivar SP79-1011 had a TC value greater than those of the other cultivars. The TC values determined in the present study are similar to those obtained by Mello et al. (2006), who evaluated sugarcane under Cwa climate conditions.

Cultivar IACSP93-6006 contained the lowest B2 fraction. The values for the $\mathrm{B} 2$ fraction were higher than the $282.2 \mathrm{~g} \mathrm{~kg}^{-1} \mathrm{DM}$ observed by Cruz et al. (2010) for sugarcane grown under Aw climate conditions.

As for the C fraction, cultivar RB83-5486 produced a lower value compared with the other cultivars. Mello et al. (2006) evaluated sugarcane cultivars grown under Cwa climate conditions and reported a higher $\mathrm{C}$ fraction value of $135.07 \mathrm{~g} \mathrm{~kg}^{-1}$ DM for the RB83-5486 cultivar. Cruz et al. (2010) evaluated sugarcane cultivars grown under Aw climate conditions and observed a lower $\mathrm{C}$ fraction value (94.0 $\mathrm{g} \mathrm{kg}^{-1} \mathrm{DM}$ ) for the cultivar SP79-1011.

The parameters related to the fiber fraction of the feed (NDF, NDFap, ADF, LIG, HEM, and CEL) were lower than those reported in the literature for sugarcane cultivated under various climate conditions. In fact, Valadares Filho et al. (2010), in a review of the chemical composition of ruminant feed, including sugarcane, observed mean levels of $544.80 \mathrm{~g} \mathrm{~kg}^{-1} \mathrm{DM}$ for NDF, $332.78 \mathrm{~g} \mathrm{~kg}^{-1} \mathrm{DM}$ for ADF, $59.40 \mathrm{~g} \mathrm{~kg}^{-1}$ DM for LIG, $209.10 \mathrm{~g} \mathrm{~kg}^{-1}$ DM for HEM, and $321.30 \mathrm{~g} \mathrm{~kg}^{-1} \mathrm{DM}$ for CEL. Thus, it can be stated that sugarcane, when grown under Af climate conditions, has a reduced level of fiber, which is a positive factor because fodders with excessive amounts of fiber can reduce the voluntary feed intake by animals.

The measured Pol values were well below those described for sugarcane grown under other climatic conditions because the climatic factors in the months preceding harvesting were not favorable to the accumulation of sucrose.

Two climatic constraints are essential for the accumulation of sucrose in sugarcane: water stress and low temperature (Cesar et al., 1987). The region has an Af climate characterized by high rainfall that is well distributed throughout the year, which is not associated with a dry period that causes the level of water stress necessary for the accumulation of sugars and, consequently, maturation. Another constraint is the thermal stress caused by low temperatures (below $20{ }^{\circ} \mathrm{C}$ ); however, this temperature is not observed in the region because of the proximity to the equator, with a mean temperature of $26.8^{\circ} \mathrm{C}$ and a minimum temperature of $22.3{ }^{\circ} \mathrm{C}$ in the months preceding the harvest. Thus, none of the two climatic constraints (water stress and low temperature) necessary for the maturation of sugarcane occurred in the studied region, indicating that the use of sugarcane grown under Af climate conditions for feeding ruminants is limited. Since sugar is the main nutrient of the sugarcane and it was found in low concentrations due to weather conditions, sugarcane grown under the Af climate should be used sparingly.

Mello et al. (2006) evaluated sugarcane cultivars grown under Cwa climate conditions and reported Pol values of 172.80 and $155.70 \mathrm{~g} \mathrm{~kg}^{-1}$ juice for cultivars RB83-5486 and SP79-1011, respectively, which are higher than those measured in the present study.

A value of 3.02 for the NDF/Pol ratio has been used to assess the nutritional quality of sugarcane and is considered indicative that the level of NDF will not limit the intake of dry matter and, consequently, of sugars, which provide the highest amount of digestible energy to animals fed sugarcane (Rodrigues et al., 2001). There was no difference in the NDF/Pol ratio among the cultivars, with a mean value of 4.08 , which is well above the value recommended by Rodrigues et al. (2001).

Under the Af climate conditions, the sucrose content, which was low in all cultivars and, consequently, increased the NDF/Pol ratio, and not the fiber fraction, may be the limiting factor for the use of sugarcane in the feeding of ruminants.

The TDN values, which were positively influenced by the high NFC levels and the low NDF and C fraction levels, were high for the cultivars grown under the Af climate conditions. The obtained values are greater than the $614.60 \mathrm{~g} \mathrm{~kg}^{-1}$ of DM for TDN reported by Valadares Filho et al. (2010).

\section{Conclusions}

The three sugarcane cultivars produce high yields of dry matter per hectare and low concentrations of fiber components. Because of the low Pol values, sugarcane grown under Af climate conditions should be used sparingly in ruminant feeding.

\section{Acknowledgments}

The authors would like to thank the Dean of Research and Graduate Studies, Pró-Reitoria de Pesquisa e PósGraduação, Universidade Federal do Pará - PROPESP/ UFPA, and Fundação de Amparo e Desenvolvimento da Pesquisa - FADESP, for the financial support for the translation of this manuscript. 


\section{References}

Almeida, A. C. S.; Souza, J. L.; Teodoro, I.; Barbosa, G. V. S.; Moura Filho, G. and Ferreira Júnior, R. A. 2008. Desenvolvimento vegetativo e produção de variedades de cana-de-açúcar em relação à disponibilidade hídrica e unidades térmicas. Ciência Agrotecnologia 32:1441-1448.

Alvarez, C. A.; Stape, J. L.; Sentelhas, P. C.; Gonçalves, J. L. M. and Sparovek, G. 2014. Köppen's climate classification map for Brazil. Meteorologische Zeitschrift 22:711-728.

AOAC - Association of Official Analytical Chemistry. 1990. Official methods of analysis. 15th ed. AOAC International, Arlington, VA.

Andrade, J. B.; Ferrari Junior, E.; Possenti, R. A.; Otsuk, I. P.; Zimback, L. and Landell, M. G. A. 2003. Seleção de 39 variedades de cana-de-açúcar para alimentação animal. Brazilian Journal of Veterinary Research and Animal Science 40:287-296.

Bonomo, P.; Cardoso, C. M. M.; Pedreira, M. S.; Santos, C. C.; Pires, A. J. V. and Silva, F. F. 2009. Potencial forrageiro de variedades de cana-de-açúcar para alimentação de ruminantes. Acta Scientiarum Animal Sciences 31:53-59.

Capone, A.; Lui, J. J.; Silva, T. R.; Dias, M. A. R. and Melo, A. V. 2011. Avaliação do comportamento de quinze cultivares de canade-açúcar na região Sul do Tocantins. Journal of Biotechnology and Biodiversity 2:70-78.

Cesar, M. A. A.; Delgado, A. A.; Camargo, A. P.; Bissoli, B. M. A. and Silva, F. C. 1987. Capacidade de fosfatos naturais e artificiais em elevar o teor de fósforo no caldo de cana-de-açúcar (canaplanta), visando o processo industrial. STAB: Açúcar, Álcool e Subprodutos 6:32-38.

CONSECANA - Conselho dos Produtores de Cana-de-açúcar, Açúcar e Álcool. 2006. Manual de instruções. 5.ed. Piracicaba, SP.

Cruz, P. G.; Figueiredo, M. P.; Pereira, L. G. R.; Bergamaschi, K. B.; Rodrigues, C. S. and Rech, C. L. S. 2010. Fracionamento e cinética da fermentação ruminal in vitro dos carboidratos de cinco variedades de cana-de-açúcar. Ciência Animal Brasileira 11:784-793.

Gilbert, R. A.; Shine Junior, J. M.; Miller, J. D.; Rice, R. W. and Rainbolt, C. R. 2006. The effect of genotype, environment and time of harvest on sugarcane yields in Florida, USA. Field Crops Research 95:156-170.

Hall, M. B. 2003. Challenges with nonfiber carbohydrate methods. Journal of Animal Science 81:3226-3232.

INMET - Instituto Nacional de Meteorologia. 2014. Belém-PA. Avaliable at: <http://www.inmet.gov.br>. Accessed on: Dec. 22, 2014.
Macêdo, G. A.; Costa, É. L.; Viana, M. C. M.; Ferreira, J. J.; Pires, J. F. and Freire, F. M. 2012. Características agronômicas e químicas das variedades de cana-de-açúcar RB83-5486 e RB86-7515 sob irrigação e sequeiro. Revista Brasileira Engenharia Agrícola Ambiental 16:599-603.

Mello, S. Q. S.; França, A. F. S.; Lima, M. L. M.; Ribeiro, D. S.; Miyagi, E. S. and Reis, J. G. 2006. Parâmetros do valor nutritivo de nove variedades de cana-de-açúcar cultivadas sob irrigação. Ciência Animal Brasileira 7:373-380.

Muraro, G. B.; Rossi Junior, P.; Oliveira, V. C.; Granzotto, P. M. C. and Schogor, A. L. B. 2009. Efeito da idade de corte sobre a composição bromatológica e as características da silagem de canade-açúcar plantada em dois espaçamentos e três idades de corte. Revista Brasileira de Zootecnia 38:1525-1531.

NRC - National Research Council. 2001. Nutrient requirements of dairy cattle. 7th ed. National Academy Press, Washington, DC.

Peel, M. C.; Finlayson, B. L. and McMahon, T. A. 2007. Updated world map of the Köppen-Geiger climate classification. Hydrology and Earth System Sciences 11:1633-1644.

Rodrigues, A. A.; Cruz, G. M.; Batista, L. A. R. and Landell, M. G. A. 2001. Qualidade de dezoito variedades de cana-de-açúcar como alimento para bovinos. p.111-113. In: Anais da $38^{\mathrm{a}}$ Reunião Anual da Sociedade Brasileira de Zootecnia. Sociedade Brasileira de Zootecnia, Piracicaba.

Sniffen, C. J.; O’Connor, J. D.; Van Soest, P. J.; Fox, D. G. and Russel, J. B. 1992. A net carbohydrate and protein system for evaluating cattle diets: II. Carbohydrate and protein availability. Journal of Animal Science 70:3562-3577.

Townsend, C. R.; Costa, N. L.; Torres, R. A.; Soares, J. P. G.; Pereira, R. G. A. and Magalhães, J. A. 2006. Avaliação agronômica de variedades de cana-de-açúcar para fins forrageiros em Rondônia. Revista Científica de Produção Animal 8:15-20.

Van Soest, P. J. 1994. Nutrition ecology of the ruminant. 2nd ed. Cornell University Press, Ithaca.

Van Soest, P. J.; Robertson, J. B. and Lewis, B. A. 1991. Symposium: carbohydrate methodology, metabolism, and nutritional implications in dairy cattle. Journal of Dairy Science 74:3583-3597.

Valadares Filho, S. C.; Machado, P. A. S.; Chizzotti, M. L.; Amaral, H. L.; Magalhães, K. A.; Rocha Junior, V. R. and Cappelle, E. R. 2010. Tabelas brasileiras de composição de alimentos para bovinos. 3.ed. Suprema Gráfica Ltda., Visconde do Rio Branco.

Valente, M. A.; Silva, J. M. L.; Rodrigues, T. E.; Carvalho, E. J. M.; Rolim, P. A. M.; Silva, E. S. and Pereira, I. C. B. 2001. Solos e avaliação da aptidão agrícola das terras do município de Castanhal, estado do Pará. Documentos n. 119. Embrapa Amazônia Oriental, Belém. p.14. 